\title{
КОНЦЕПЦІЯ «МОВНОї ГРИ» Л. ВІТГЕНШТЕЙНА
}

\begin{abstract}
А.С. Синиця
В першій половині XX століття в аналітичній філософії існувало два основні підходи до аналізу природи мови: логічний і лінгвістичний. В межах першого підходу предметом дослідження аналітичних філософів виступала логічно сконструйована (ідеальна) мова. Основною парадигмою логічного аналізу мови була концепція «логічного атомізму», сформульована Б. Расселом та раннім Л. Вітгенштейном.

Рассел визначав «логічні атоми» як кінцеву мету аналізу, що утворюють основні, базові елементи реальності. В якості таких елементів Рассел розглядав факти, а філософія, на його думку, визначається як аналіз можливостей логічного конструювання світу із чуттєвих даних за допомогою інструментарію математичної логіки. Логічні атоми це логічні конструкції із чуттевих даних; це «факти», якими може оперувати філософ.

Факт сам по собі не $\epsilon$ ані істинним, ані хибним. Істина чи хибаце властивості висловлювань про факти. Висловлювання вважається істинним, якщо інформація, яка в ньому закладена відповідає факту, в іншому випадку, висловлювання вважається хибним. Джерелом істинності чи хибності елементарних висловлювань $є$ чуттєві сприйняття.

Філософія логічного аналізу мови була піддана критиці за їі метод аналізу досить далекий від практики розмовної мови, за дещо незадові.льне вирішення парадоксальних ситуацій, пов'язаних з одиничними іменами, за штучність більшості сконструйованих понять тощо. Чи не найбільшими критиками цього підходу виявилися саме представники лінгвістичної філософії, які предметом свого аналізу визначили природну мову.
\end{abstract}

Актуальні проблеми духовності

(Відп. ред.: Я.В.Шрамко)

Кривнй Pir (2008), 126-133 
Аналіз природної мови - це нова парадигма досліджень в межах аналітичної філософії, яка лягла в основу лінгвістичної філософії, оригінального філософського напряму, що виник в 1950-х роках і набув великої популярності в англомовних країнах.

Лінгвістична філософія постала з необхідності усвідомлення неможливості редукції плюральності мовних емпірій до деякої «праструктури», тобто ідеальної логічної мови, вільної від двозначностей, суперечностей і неточностей буденної мови. Даний філософський напрям не визнавав традиційний техніцизм філософії, формалізований аналіз у його феноменалістичному і фізикалістському варіантах. Е. Гелнер, на нашу думку, вірно відзначав, що «в основу ідей цього напряму покладена претензія або надія на те, що усвідомлення мови або деяких раніше проігнорованих її особливостей повністю змінить нашу точку зору в майбутньому» $[3$, с. 30]. Тобто вивчення природної мови виступае для лінгвофілософів першочерговим завданням.

Представники лінгвістичної філософії збагатили категоріальний апарат сучасних аналітиків в першу чергу такими термінами як «мовна гра», «буденна мова», «мовні акти», «неформальна логіка», «іллокуція», «перформативи» тощо.

Серед найбільш відомих представників цього напряму, чиї праці вплинули на розвиток філософської думки, можна виділити Дж. Уіздома, Г. Райла, Дж. Остіна i, звичайно, Л. Вітгенштейна. Останній у своїй творчості пройшов еволюцію від філософії логічного аналізу мови (ранній період творчості), до аналітико-філософського осмислення природної мови (пізній період творчості).

Аналітико-філософський підхід до осмислення природи мови (виражений у концепції «мовної гри»), орієнтований в першу чергу на виявлення її семантичних і прагматичних аспектів, був запропонований Л. Вітгенштейном в «Філософських дослідженнях».

Л. Вітгенштейн, створюючи концепцію «мовної гри», усвідомив неможливість розгляду мови 3 позиції «безособового представлення світу». Австрійський філософ у пізній період своєї творчості відкинув можливість зведення буденної мови до сутнісної основи, вираженої мовою логіки; піддавав сумніву тезу про неадекватність буденної мови для науки; не погоджувався з тим, що штучно сконструйована мова науки описуе факти в чітко визначений спосіб.

Зазначимо, що термін «мовна гра» потребує уточнення, виходячи iз значень англійської мови, в якій для позначення поняття гри використовуються два слова: «game» $\mathrm{i}$ «play». В першому випадку йдеться про дотримання правил, в другому про дію («грати», «діяти»). 
Л. Вітгенштейн, вживаючи поняття «language-game» («мовна гра»), прагнув наголосити на важливості правил в процесі творення ігор. Але він не поділяв думки, що можливо представити мову як «числення правил значення». Справа в тому, що система правил буденної мови не $є$ повною і однозначною, а тому неможливо буде їі систематизувати в числення. Вітгенштейн прагнув довести, що ми не можемо остаточно бути переконаними в тому, що наше розуміння деякого правила завжди буде тотожне розумінню цього правила нашим співрозмовником, а сама дія правила незмінно буде визначена по відношенню до безкінечної множини часткових випадків. Це так звана проблема стабільності мовних значень, тобто визначення факторів, що забезпечують незмінність вживання значень мовних виразів.

Використання мовних правил повинне бути усвідомленим, а не механічним і базуватися на узгодженні вживання цього знаку іншими членами мовної спільноти.

В кожній грі можна розрізняти як суттєві, так і несуттєві правила. Недотримання, або ж зміна першого роду правил повністю змінюе образ гри. Наприклад, у грі в футбол, якщо ми заборонимо грати ногами і дозволимо грати руками, то це суттєво змінить сам характер гри. В той час як дозвіл продовжувати гру в офсайді (несуттєве правило) не змінить суті футболу.

Крім важливості правил в процесі комунікації, мало зафіксувати в філософській термінології практичний характер мови, необхідно також зафіксувати іï прагматичний аспект, який був відсутній в штучно сконструйованих (формально-логічних) мовах.

«Мовні ігри» можуть виникнути лише в середовищі, яке відповідає наступним умовам:

1) Наявність мовного співтовариства. Адже мова є іманентною людською властивістю і якщо немає носіїв мови, то і не має самої мови. Більш того, мова повинна використовуватись, інакше їй неодмінно загрожуе занепад і знищення.

2) Слова, які вживаються в процесі гри, як нами, так і нашими співрозмовниками повинні розумітись адекватно. А це означає, що кожен 3 учасників гри має дотримуватись чітко встановлених правил.

3) Порушення правил мовної гри повинне засуджуватись іншими членами співтовариства, інакше це може призвести до непередбачуваних, а то і руйнівних наслідків.

Вищенаведені умови необхідні не лише для виникнення, але і ефективного функціонування «мовних ігор». Отже, як можна побачити, 
поняття «мовної гри» не просто фіксуе характер інтерсуб'єктивних реалій [4]. Це поняття окреслюе ще й велику сукупність екстернальних умов. Дані умови, визначаючи, так би мовити, особливості мовного середовища, нічого не говорять нам про природу мовних ігор, навіть не регламентують їх кількість.

Побудову концепції «мовної гри» Л. Вітгенштейн починає 3 критики однієї 3 найбільш популярних теорій значення - «августиніанської» (названої на честь Св. Августина).

Згідно 3 «августиніанською» теорією, значення слова $\boldsymbol{e}$ визначеним предметом (абстрактною сутністю; образом свідомості тощо), за який воно (слово) відповідає. Але такому визначенню в мові відповідають лише іменники, а інші частини мови залишаються не врахованими. Виглядає так, наче спочатку потрібно задати значення іменників (шляхом вказування на відповідні їм предмети), а значення, скажімо, назв діяльності чи їх властивостей, в подальшому з'ясовуються самі собою. Будуючи концепцію «мовної гри», Вітгенштейн пропонуе новий механізм засвоєння значень мовних виразів. Але спершу він задається питанням, що е властиве всім іграм? Для того, щоб усвідомити різноманіття всіх мовних ігор Вітгенштейн наводить наступні приклади останніх:

«Давати накази й діяти згідно з ними;

Описувати предмет за його виглядом або розмірами;

Виготовляти предмет за його описом (малюнком);

Висувати й перевіряти гіпотезу;

$\ldots$

Вигадувати й читати оповідки;

Прикидатися;

Співати в хороводі;

Відгадувати загадки;

...

Просити, думати, лаяти, вітати, молитися» [2, с. 101-102].

Вищенаведений перелік повинен показати, що потенційні властивості, яким мають відповідати ігри, не поширюються на всю їх множину. Наприклад, суперництво, притаманне більшості спортивних ігор, не $\boldsymbol{\epsilon}$ ознакою мовних ігор. Ігри не можна уніфікувати, тобто знайти для них необхідну спільність. Будь-яке теоретизування з метою чіткого визначення концепту «мовної гри» приречене на невдачу. Мовні значення наповнені різними смислами. Вітгенштейн говорить про необхідність 
існування багатозначних мов і виразів. Для того щоб пояснити як вони взаємодіють між собою, тобто як взаємодіють між собою різноманітні «мовні ігри» він вводить поняття «явищ сімейної схожості» (або ж «родинних подібностей»), які проявляяються більшою чи меншою мірою: «Ті подібності найкраще охарактеризувати словами „родинні подібності“, бо так поширюються одні на одних і схрещуються одні з одними різні подібності, що існують між членами родини: ріст, риси обличчя, колір очей, хода, темперамент і т. д., і т. д. - I я кажу: ,ігри“ утворюють родину» $[2$, с. 122$]$.

«Мовна гра»-це особливий вид діяльності, спосіб життя, за допомогою якого відбувається опис властивостей навколишньої дійсності крізь призму множини речень. Кожне з цих речень може, щось стверджувати чи заперечувати, виражати необхідність вибору чи пошуку.

Утворення кожного речення регламентоване чітким набором правил, визначених «аспектом бачення». Сам Вітгенштейн розрізняв «постійне бачення» аспекту від «миттєвого погляду» на аспект. Для наочної ілюстрації цього розрізнення він пропонуе звернутися до фігури «голови качко-зайця» Джестрова. При першому способі бачення фігура постае піілісною, тобто образом голови і качки і зайця. При «миттєвому баченні» ми виділяємо лише окремий аспект: чи то голову качки, чи то голову зайця. Зміна аспекту змінюе і ситуацію, роблячи потенційні переживання ситуації дійсними, а дійсні-потенційними. Під ситуацією слід розуміти певний стан справ, який сприймається і аналізуеться суб'єктом. Людина гіпостазуе (наділяе існуванням) свої переживання з метою створення більш адекватного і цілісного уявлення про об'єкт. Хоча Вітгенштейн не виключає можливості появи не лише безглуздих мовних виразів, але й безглуздих уявлень. Також слід враховувати, що людина аналізуе не уявлення, а поняття. Поняття $e$ знарядлями, які провадять нас до досліджень в різноманітних сферах наукової і творчої діяльності.

Згідно $з$ філософією пізнього Вітгенштейна характерною особливістю мовних ігор є відмова від єдиної логічної форми мови. Будьякий вид діяльності має свою логіку і свою мову. Вітгенштейн показує залежність логіки людського мислення від значень і смислів слів, фраз, які ми вживаемо: «Значення фрази для нас характеризуеться її вживанням» $[1$, с. 113].

у цьому контексті необхідно розрізняти між «вживанням слова» $\mathrm{i}$ його «використанням», а також між «вживанням слова» $\mathrm{i}$ «вживанням мови».

Вживання слова не слід ототожнювати з його використанням. В 
основі механізму вживання лежить деяка схема, яка визначае те, що саме слово не може виразити. Контекст вживання слова $\boldsymbol{\epsilon}$ інтерпретацією наших уявлень. Використання слова в певних мовних контекстах, тобто місце яке це слово в них займае, визначається всією сукупністю знаків. Із вживанням і використанням слова пов'язане і їх розуміння. Розуміння - це певний стан (який не слід ототожнювати виключно 3 психічним станом), що визначае правильне застосування мовних виразів. Коли ми починаємо щось розуміти ми опановуємо певну техніку поводження у відповідних ситуаціях. Близькими з точки зору граматики (а Вітгенштейн визначав аналіз як такий, що має спільне від природничого і граматичного підходів) до слова «розуміти» є слова «знати», «уміти», «бути здатним». Для того, щоб щось зрозуміти ми повинні його описати. Мовна гра і $є$ описом стану речей.

Я. Хінтікка пише, що деякі філософи розрізняли значення «вживання слова» i «вживання мови»: «Під першим філософи мають на увазі використання слів для утворення висловлювань і для позначення. Кажучи ж про використання мови, філософи за звичай мають на увазі різні мовні або мовленневі акти, які здійснюються шляхом написання або артикуляції висловлювань. Таким, чином вживання мови полягає в написанні або промовлянні чогось» $[7$, с. $246-247]$. Але коли ми промовляемо певний мовний акт, то його значення залежить і від певного соціального контексту. Наприклад, дієслово-звертання «Перепрошую» втрачає своє значення, якщо в межах певної мовної спільноти не має звичаю перепрошувати за певні дії.

Наголошуючи на тому, що значення слова $є$ його вживанням в межах певної мови, Вітгенштейн прагнув показати, що багатьох філософських проблем можна позбутися, знаючи науку про мову.

Підсумовуючи основні моменти концепції «мовних ігор» Вітгенштейна, зазначимо, що «мовні ігри» виступають спрощеними формами вживання мовних виразів і $є$ ключем до аналізу більш складних лінгвістичних випадків. «Мовні ігри»-це єдність дій і вкоріненої в них мови.

Концепція «мовних ігор» Вітгенштейна викликала одразу чималі суперечки і критику в науковій спільноті. Наприклад, Мур заперечував точку зору Вітгенштейна, згідно з якою висловлювання можна вважати істинним, якщо ніхто не може довести його хибність. Б. Рассел критикував Вітгенштейна за відмову від основних положень його «Логіко-філософського трактату».

Проте концептія «мовних ігор» знайшла й чимало прихильників, як серед філософів, так і серед логіків. Хоча кожен з них по своєму 
іiї інтерпретував. Так Г. Райл розвивав ідеї Вітгенштейна про існування особливої мовної поведінки, що виникає в процесі навчання грі, але відкидав спроби автора «Філософських досліджень» знайти логіку в межах буденної мови, яка завжди демонструвала свою глибинну нелогічність. 3 іншої сторони розвиток логічної складової концепції «мовних ігор» американським логіком С. Кріпке знайшов своє місце в побудові семантики «можливих світів».

Окрім семантики «можливих світів», концепція «мовних ігор» Вітгенштейна мала найбільший вплив на розвиток теоретико-ігрової $\mathrm{i}$ критеріальної семантик. Можемо сказати, що більшість сучасних семантик певним чином торкаються концепції «мовних ігор» Вітгенштейна, за рахунок використання поняття «семантичної відносності», яке фіксуе можливість набуття відмінного істиннісного значення певним висловлюванням в залежності від того, що вважати для нього найбільш важливим і визначальним.

В. Петров, порівнюючи семантику «можливих світів» (теоретикомодельну) і теоретико-ігрову семантику, зазначає: «Якщо теоретикомодельна семантика достатньо жорстко регламентуе природну мову, то теоретико-ігрова семантика більшою мірою оріентована на експлікацію процесів і подій» [5, с. 21]. Теоретико-ігровий підхід дозволяе інтерпретувати проблеми, що належать до компетенції семантики тексту (анафори, дискурсивні феномени тощо).

Теоретико-ігрова семантика Я. Хінтікки є більш процесуально-орієнтованою, ніж теоретико-модельна семантика, оскільки використовує в процесі аналізу істиннісного значення певного висловлювання - поняття гри, яке являє собою основну інтерпретаційну одиницю і вводить в дослідження нові параметри («пам'ять», «інформаційна множина»), які згодом слід використовувати в семантичному аналізі. Теоретикоігрова семантика $\boldsymbol{\epsilon}$ більш зручною для аналізу, а сфера її інтерпретації більш ширшою, ніж у теоретико-модельної семантики.

Що стосуеться концепції «мовних ігор», навіть не зважаючи на те, що Я. Хінтікка високо оцінював поняття гри, запропоноване Л. Вітгенштейном, інтерпретація цього поняття набула у нього відмінних рис. В. Садовський та В.Смирнов у зв'язку з цим зазначають: «Якщо у Л. Вітгенштейна лінгвістична гра є лінгвістичним спілкуванням суб'єктів у визначених життевих ситуаціях ..., то у Я. Хінтікки ігрова ситуація - це ситуація взаємодії суб'єкта і природи» [6, с. 21].

На відміну від теоретико-ігрової семантики Хінтікки, де ключовим поняттям являеться поняття «гри», в критеріальній (конструктивістській) семантиці, витоки якої слід шукати в ідеях філософії пізнього 
Вітгенштейна, центральним поняттям $e$ «критерій», в термінах якого і аналізуеться значення мовних виразів. На відміну від теоретикомодельної семантики в критеріальній семантиці вирішальну роль починає відігравати людина як носій і інтерпретатор мови, а не дещо абстрактне поняття мови (як це мало місце в теоретико-модельній семантиці).

Аналіз, проведений нами в цій статті, засвідчуе, що концепція «мовних ігор» за своєю суттю являється настільки новаторською і багатогранною, що її еволюція в різного роду семантичних модифікаціях і на сьогодні не вичерпала свій потенціал, залишившись доволі перспективною темою для досліджень.

\section{1 Бібліографія}

[1] Витгенитейн Л. Голубая книга. - М.: Дом интеллектуальной книги, 1999.

[2] Вітгенитайн Л. Філософські дослідження // Вітгенштайн Л. Tractatus logico-philosophicus; Філософські дослідження. - K.: Основи, 1995. - С. 87-309.

[3] Геллиер Ө. Слова и вещи.-М.: Из-во иностранной литературы, 1962.

[4] Козлова М.С. Идея «языковых игр» // Философские идеи Людвига Витгенштейна. - Ин-т философии РАН, 1996. - С. 5-25.

[5] Петров B.B. Язык и логическая теория // Новое в зарубежной лингвистике. Вып. 18. Логический анализ естественного языка.М.: Прогресс, 1986. - С. 5-23.

[6] Садовсъкий B.Н., Смирнов В.А. Я. Хинтикка и развитие логикоэпистемологических исследований во второй половине $\mathrm{XX}$ века (Вступительная статья) // в кн. Хинтикка Я. Логико-эпистемологические исследования. - М.: Прогресс, 1980.-С.5-32.

[7] Хинтикка Я. Языковые игры для кванторов // Хинтикка Я. Логико-эпистемологические исследования. - М.: Прогресс, 1980.C. 245-280. 